DOI: https://doi.org/10.18371/fp.3(35).2019.190172

УДК 336.77

\title{
ЗАХИСТ ПРАВ СПОЖИВАЧІВ КРЕДИТНИХ ПОСЛУГ ЧЕРЕЗ АЛЬТЕРНАТИВНІ ІНСТРУМЕНТИ ФІНАНСУВАННЯ В УМОВАХ ЦИФРОВОÏ ЕКОНОМІКИ
}

\author{
ПОЛЯХ Сергій Сергійович \\ викладач кафедри фінансів та банківської справи \\ Черкаського навчально-наукового інституту \\ ДВНЗ «Університет банківської справи» \\ ORCID ID: http://orcid.org/0000-0001-6825-5083 \\ e-mail:poljashonok@ukr.net
}

Анотація. У статті проведено аналіз основних напрямів впливу цифровізації економіки на розвиток кредитного ринку в Україні, приведені ключові аспекти небанківського кредитування. Досліджено проблеми законодавчого забезпечення прав споживачів при залученні кредитних коштів через альтернативні інструменти фінансування. Сформовані напрями поліпшення проведення політики захисту прав споживачів та визначені заходи мінімізації ризиків онлайн кредитування на рівні законодавства України та державних регулюючих органів.

Ключові слова: захист прав споживачів, кредитні послуги, Fintech, мікрокредитування, альтернативні інструменти фінансування, державне регулювання.

Постановка проблеми. Трансформація фінансового ринку під впливом цифрової економіки зумовила прискорений розвиток його сегмента - ринку небанківських фінансових послуг. Основним детермінантом якого стала поява нових форм кредитування, що відкрила доступ до швидко доступних
Аннотация. $B$ cmaтье проведен анализ основных направлений влияния ичифровизации экономики на развитие кредитного рынка в Украине, приведены ключевые аспекты небанковского кредитования. Исследованы проблемы законодательного обеспечения прав потребителей при привлечении кредитных средств через альтернативные инструменты финансирования. Сформированы направления улучшения проведения политики защиты прав потребителей и определены меры минимизации рисков онлайн кредитования на уровне законодательства Украины и государственных регулирующиих органов.

Ключевые слова: защчита прав потребителей, кредитные услуги, Fintech, микрокредитования, альтернативные инструменты финансирования, государственное регулирование.

коштів без жорстких вимог до позичальників.

Однак виникає необхідність належного держаного регулювання на ринку небанківського кредитування 3 метою мінімізації порушень та захисту законних прав та інтересів кредитодавців та споживачів. 
Аналіз останніх досліджень i публікацій. До науковців, які досліджували державне регулювання ринку небанківських фінансових послуг в-Україні, можна віднести О.І..Барановського, Клименко О.В., Левченко В.П., Пінчук А.П., Бачо Р.Й. та інші.

Однак сучасні трансформації небанківського фінансового сектору, а саме поява можливості залучення кредитних коштів через альтернативні інструменти фінансування, зумовлюють потребу дослідження в сфері захисту прав споживачів на законодавчому рівні.

Метою статті $\epsilon$ наукове дослідження розвитку ринку небанківських фінансових послуг в умовах цифрової економіки, в аспекті правового регулювання захисту прав споживачів та формулювання на підставі цього пропозицій щодо вдосконалення чинного законодавства України.

Виклад основних результатів. На початку 2019 року в Україні процес діджиталізації перебуває на вершині свого розвитку і проникає в усі сфери людського життя в тому числі у фінансових сектор. Поряд 3 традиційними постачальниками фінансових послуг з'являються нетрадиційні, більшість яких засновані як стартапи у секторі фінансових технологій (FinTech).

Світовий ринок FinTech нещодавно почав розвиватися, проте вже нараховує понад 1500 компаній FinTech в країнах Свропи, а також компанії, які раніше діяли в інших галузях (наприклад, управління активами та інформаційно-комунікаційні технології), та почали вивчати можливість пропонувати роздрібні фінансові послуги.

Однак розмір даного сектору є незначним порівняно 3 традиційним банківським сектором наприклад, загальні активи найбільшої компанії FinTech, Klarna, у 2017 році становили 12,8 млн. євро, в той час як активи найбільшого банка становили 2076 мільярдів, найбільший традиційний страховий провайдер AXA, мав у своєму розпорядженні 802 млрд. євро.

Згідно $з$ даними, представленими на веб-ресурсі «Statista» за 2018 рік сумарна вартість транзакцій у секторі FinTech становить 682 млрд. євро, порівняно 3 1,415 млрд. євро в Китаї, 1,146 млрд. євро, у США та 152 млрд. євро, в Японії. За прогнозованим значенням загальний ріст вартості транзакцій у секторі FinTech, в країнах Європи, до 2022 року буде становити 13,3\% (1,082 млрд. євро). У свою чергу середня вартість транзакцій збільшиться на 51,7\%, а саме 31343 євро в 2018 році до - 2038,26 євро в 2022 році [1].

Кількість користувачів продуктів FinTech в Європі становить 508 мільйонів, і прогнозується, що до 2022 року вона зросте на 4,5\% і становитиме 531 мільйонів користувачів.[1]

В Україні завдяки розвитку Fintech були створені принципово нові вебплатформи, пристосовані для роботи 3 персональними даними та фінансовими операціями. З'явилися нові компанії, які використовують сучасні технології для створення нових видів фінансових послуг на ринку небанківського мікрокредитуванні, а також онлайн-кредитування. 
Бурхливе зростання інтернеткредитування в Україні почалося в другій половині 2018 року. А вже на початку 2019 року кількість договорів кредитування, укладених фінансовими компаніями дистанційно, було понад 1,5 млн. шт., що на 113\% більше, ніж за аналогічний період минулого року. Станом на 01.01.2019 року кредити в інтернеті видають 70 фінансових компаній. При цьому на топ-20 припадає $91 \%$ обсягу виданих онлайн-позик і $86 \%$ кількості укладених дистанційно договорів. В середньому кредит видається на 15-30 днів, під 1-2\% в день, на суму від 3 до 10 тисяч грн. [2]

Основним продуктом ринку онлайн кредитування $\epsilon$ швидкі онлайн кредити небанківських мікрофінансових компаній. В українському законодавстві, на відміну від інших країн, поки не закріплені такі поняття, як «небанківські мікрофінансові компанії (організації)» (далі МФО) та «мікрокредитування». Також відсутнє поняття «кредитування онлайн», але це не означає, що така діяльність незаконна.

Переважна більшість онлайн кредитів - це мікрокредити, тобто позики на невелику суму до зарплати, максимум на 1 місяць. На відміну від банків, які ніколи не дають кредити людям 3 поганою кредитною історією, малі фінансові компанії позичають майже всім, але під дуже великі відсотки - від $320 \%$ до $720 \%$ річних. Причина в тому, що конкурувати з банками досить складно, тому мікрофінансові кредитні компанії працюють 3 такими клієнтами, для яких банківські кредити недоступні. [3]
1.Можна визначити наступні ТОП 10 фінансових організацій, на українському ринку що пропонують онлайн кредитування [2]: MyCredit, PayPong, Money24, KLT Credit, Moneyveo, CreditON, Credit365, Глобал кредит. CCLoan, CashME.

Для оформлення мікропозики в МФО обов'язковим $є$ надання таких даних:

- цифрова копія паспорта;

- цифрова копія ідентифікаційного номера;

- реквізити та данні банківської картки (з мінімальним залишком в 1 грн для верифікаціі);

- місце роботи;

- адресу проживання;

- сімейний стан, наявність дітей.

Відповідно до отриманої інформації про інтернет-кредитування, можна виділити наступні переваги для клієнтів даного сервісу:

1. Швидке схвалення. Кредитори в мережі Інтернеті можуть більш-менш миттєво повідомити вас про те, чи затверджена ваша позика, максимальна сума позички та розмір ваших платежів. Як приклад банківські установи, при оформлені заявки в Інтернеті, для надання відповіді може знадобитися певний час, а в деяких випадках і необхідність відвідати відділення особисто.

2. Легше схвалення. У випадку відсутності кредитної історії або негативної кредитної історії Інтернеткредитори мають більше шансів затвердити позику, оскільки у них нижчі кредитні оцінки. В основному МФО використовують «альтернативні» джерела інформації для оцінки вашої кредитоспроможності (наприклад, кому- 
нальні платежі та дані 3 ваших соціальних мереж).

3. Незабезпечені позики. Більшість кредитів в Інтернеті є незабезпеченими, а це означає, що ви не зобов'язуєтеся забезпечити заставу, щоб допомогти отримати схвалення. У випадку непогашення незабезпеченого кредиту, зміняться лише ваші кредитні показники (серед іншого), але ви не зіткнетесь із стягненням та втратою майна.

Крім переваг визначимо основні ризики 3 якими стикаються клієнти при онлайн кредитуванні:

1. Непрозорість цін. Ціни не є прозорими для типового споживача, зокрема, це стосується їх вартісної складової. Багато фінансових продуктів та послуг є комплексними i, як наслідок, мають нелінійну структуру ціноутворення. Цей фактор може викликати у клієнта відчуття недовіри до того чи іншого фінансового інституту. Крім того навіть якщо клієнт отримає кредит, то в кінцевому підсумку може заплатити набагато більше, оскільки у вартість фінансової послуги оператори також закладають відповідальність позичальника у вигляді пені за прострочення повернення заборгованості. У зразку договору Moneyveo зазначено 1,3\% за день або близько $475 \%$ за рік, в MyCredit пеня становить 1,6\% (585\% річних), в MiLoan - 1,8\% (660\% річних), в Dinero - $1,5 \%(550 \%$ річних) $[4,5,6,7]$.

2. Втрата грошей - це реальний ризик: недобросовісні (підроблені) кредитори можуть легко створити магазин, надати безліч обіцянок та стягувати збори за затвердження вашого кредиту. Зрештою, споживач не отри- мує те, за що заплатив. Аналізуючи ринок інтернет-кредитування можна виявити такі основні загрози:

- «Афера за авансовий збір» (попередні фінансові збори) зазвичай використовується злодіями, які пояснюють, що потрібно сплатити певну суму коштів для обробки поданої заявки. В практиці оформлення кредитів $\epsilon$ перелік законних вимог кредиторів на оплату певних послуг по оформленню позики, які коштують грошей, щоб подати заявку, але це, як правило, великі позики, наприклад позики на житло (плата за перевірку кредиту, оцінку тощо), і ці збори чітко пояснюються - часто при офіційному розголошенні документа.

- Гарантія схвалення позики: кредитори не займаються бізнесом, щоб втрачати гроші, тому вони не можуть гарантувати, що вони будуть позичати комусь. Деякі кредитори готові ризикувати більше, ніж інші, але їм все одно потрібно певна інформація про ваші фінанси для оцінки ризику. Якщо у вас немає (або погана) кредитна історія, відсутній дохід та немає ніяких активів, які можна використати в якості застави, кредитор не може бути впевнений, щодо повернення своїх коштів. Кредитори, які схвалюють "будь кого", мають спосіб заробити високі прибутки в обмін на великі ризики, тобто це свідчить про високу плату за позику або даний кредит направлений на крадіжку коштів або персональних даних.

- Запит на отримання коштів за допомогою переказу коштів: кредитори вимагають оплати банківським переказом або іншими послугами миттевої оплати (наприклад, Western Union 
або MoneyGram) за оформлення позики. В більшості випадків це афера. Щойно ви надсилаєте кошти, гроші втрачаються назавжди, і майже неможливо ідентифікувати отримувача цих кошти. 3 іншого боку, кредитор, який приймає чеки, повинен мати «чистий» банківський рахунок для здачі цих чеків (які правоохоронці легко знайти), а процесори кредитних карток швидко закривають постачальників із великою кількістю скарг.

- Непрофесійні продажі та обслуговування: як правило це «примітивний» веб-сайт, сповнений неправильно написаних слів та інших помилок. В основному це $\epsilon$ ознакою того, що ви маєте справу 3 шахраями. Помилки безпеки у вашому браузері також $\epsilon$ поганим знаком.

3. Викрадання особистих даних: при передачі своєї особистої інформації злодіям (особистих даних) або надаєте її на веб-сайт, який не має захисту інформації належним чином. Інформація, яка зазвичай зустрічається у заявах на позику, дуже корисна для крадіжки особи споживача: паспортні данні, номер ідентифікаційного коду, дата народження, поточна та попередня адреси тощо.

Проаналізувавши переваги та недоліки інтернет-кредитування, виникає необхідність дослідити дане питання не тільки на рівні клієнта, а й на рівні законодавства України та державних регулюючих органів.

В червні 2017 року набрав чинності Закон України «Про споживче кредитування», що мав на меті підвищення рівня захисту прав споживача як вразливої сторони кредитних правовідносин. Закон надає позичальнику широ- ке коло прав у відносинах 3 фінансовими установами, а саме:

- отримати вичерпну інформацію про умови кредитування до укладення договору;

- відмовитись від кредитного договору протягом 14 днів 3 моменту укладення;

- раз на місяць отримувати інформацію про стан виконання зобов'язань та розмір заборгованості;

- достроково повернути кошти без додаткових платежів;

- право на обмеження розміру пені за простроченим зобов'язанням у розмірі $15 \%$ суми боргу та загальної суми штрафів і пені - половиною суми отриманих кредитних коштів. [8]

Однак 3-під дії цього закону було виведено деякі категорії кредитів. Закон не поширюється на договори, що містять умову про споживчий кредит у формі кредитування рахунку зі строком погашення кредиту до одного місяця, кредитні договори, що укладаються на строк до одного місяця, а також кредитні договори, загальний розмір позики за якими не перевищує однієї мінімальної зарплати, встановленої на день укладання кредитного договору. Тобто, якщо споживач взяв кредит менше ніж на місяць або на суму до 4173 грн (розмір мінімальної зарплати у 2019 році), то гарантії надані державою не працюватимуть.

Невизначеним залишається питання щодо переліку кредитних договорів, які не регулюються Законом України «Про споживче кредитування». До них належать кредитні договори зі строком дії до одного місяця та кредити, розмір яких становить менше ніж розмір однієї мінімальної заробітної 
плати. До таких послуг відносяться й інтернет-кредити.

Так наприклад, Павло Крапівін, голова об'єднання фінансових установ України, зазначає, що «до такого бурхливого зростання інтернеткредитів ні сам ринок, ні регулятор не були готові». Доказом проблемності даного питання $\epsilon$ звернення члену керівництва Нацкомфінпослуг, Дениса Ястреба, в офіційному повідомлені на сайті державного регулятора, що «Комісія визначає значне збільшення поданих заяв та скарг споживачів послуг саме по онлайн-кредитуванню». Основними причинами такого стану ринку $є$ відсутність необхідних ITрішень і єдиного підходу в питаннях ідентифікації клієнтів. В результаті шахраї могли скористатися відкритими даними громадян України і за чужими документами взяти онлайнкредит. Як наслідок виникло невдоволення як з боку позичальників, так і 3 боку кредиторів, що змусило регулятора на початку 2019 року вживати термінових заходів для регулювання ринку онлайн-кредитування. [Ошибка! Закладка не определена.]

Першочерговим кроком Нацкомфінпослуг, щодо регулювання було визнання всіх договорів, де порушені процедури акцептування (акцепт означає згоду на передачу грошових коштів за договором, - ред.), недійсними. Основними кроками регулятора по вирішенню даного проблемного питання були такими:

По-перше, Нацкомфінпослуг почала проводити семінари 3 лідерами ринку онлайн-кредитування, на яких обговорювалися проблемні питання та шляхи зниження кількості скарг позичаль- ників. У свою чергу, фінансові компанії почали удосконалити свої ITрішення і сайти для правильної ідентифікації клієнтів і акцептування оферти. До фінансових компаній, які не хотіли цього робити, Комісія почала застосовувати заходи впливу - приписи.

По-друге, регулятор розробив i в лютому 2019 році розмістив на сайті інформаційне повідомлення про порядок укладання електронного договору. В червні було розроблене та видане розпорядженням №1033, в якому затверджені «Методичні рекомендації щодо укладання електронних кредитних договорів», які визначають основні вимоги до того, як оформляти i підписувати договори позик, ідентифікувати клієнтів, захищати інформацію [9]

По-третє, Комісія Нацкомфінпослуг розпорядженням № 1853 від 20.09.2019 року заборонила фінкомпаніям нараховувати пеню і штрафи за кредитами понад 50\% від заборгованості клієнта. Хоча дану умову вимагає закон «Про споживче кредитування», але багато фінкомпанії цю вимогу ігнорують. [10]

По-четверте, за настійною рекомендацією регулятора фінкомпанії стали активніше співпрацювати з бюро кредитних історій (БКІ). Тільки в травнічервні працювати з БКР почали такі учасники ринку онлайн-кредитування, як «AIA Фінанс груп», «ФК» Ніко Капітал», «ФК «Форза», «Фінтеч Лаб», «ФК «Кредітон».

Дані рішення не мають комплексного характеру, в основному направленні на зменшення кількості скарг та заяв від споживачів. До основних про- 
блем українського законодавства в сфері регулювання ринку кредитування небанківськими фінансовими установами варто віднести:

1. Кіберзлочинність.

2. Відсутність обов'язкових вимог для фінансових компаній передавати інформацію про позичальника в бюро кредитних історій.

3. Належна ідентифікація і верифікація клієнтів.

Для вирішення даних проблем необхідний комплексний підхід на законодавчому рівні. Пропонується використати найкращі практики країн Свропейського союзу та Сполучених Штатів Америки.

В 2019 році Європейським союзом проводилось «Навчальне дослідження диджіталізації маркетингу i дистанційні продажі фінансових послуг» [11]. Цілями даного дослідження $\epsilon$ визначення кращих практик реклами та переддоговірні етапи під час пошуку та придбання роздрібних фінансових послуг в Інтернеті, оцінити вплив цих практик та відповідних засобів захисту споживачів фінансових послуг.

Дане дослідження включало експерименти та опитування 8451 споживачів у шести країнах (Фінляндія, Франція, Німеччина, Литва, Румунія, Іспанія та Росія ). Експерименти повторювали рекламні та переддоговірні етапи процесу придбання особистої послуги через мережу Інтернет та визначали вплив ряду комерційних практик та відповідних засобів захисту споживачів, щодо можливості вибору оптимальних умов позики. Експерименти моделювали як на настільних так i на мобільних при- строях, а респонденти випадковим чином були розподілені між ними на ці два налаштування.

Експеримент включав такі дослідження:

1) У дослідженні було випробувано засіб, який свідомо сповільнив оформлення споживачами позики шляхом збільшення кількості «кліків», необхідних для вибору позики. Результати показали, що незначне збільшення кількості кліків покращує прийняття рішень споживачами, але лише до певного моменту. Якщо процес занадто сповільнений, користь навпаки зникає.

2) Визначено, що споживачі негативно сприймають орієнтацію та персоналізацію при рекламі продукції. Однак науковці визнають, що докази про вплив використання цих практик, щодо добробуту споживачів неоднозначні.

3) Результати експерименту дозволили припустити, що ефективним засобом боротьби 3 потенційними негативними наслідками взаємозв'язку між клієнтом та надавачом послуги шляхом Інтернету є чіткі вказівки (наприклад, онлайн-калькуляторів). Експеримент показує, що споживачі прагнуть використовувати їх. Однак ці інструменти ефективні лише у тому випадку, якщо споживачі зможуть ними користуватися правильно.

В США у вересні 2018 року Федеральною комісією 3 торгівлі (Federal Trade Commission's) був прийнятий єдиний закон, щодо захисту споживачів від крадіжки персональних даних та оформлення шахрайських кредитів. Закон передбачає, що споживачі, які стурбовані крадіжкою особи або по- 
рушенням даних, можуть заморозити свій кредит та безкоштовно подати однорічні сповіщення про шахрайство та отримати регуляторну допомогу, щодо захисту своїх прав. Замороження кредиту обмежує доступ до кредитного файлу споживача, що ускладнює злодіям особи, які відкривають нові рахунки на ім'я споживача [12].

Попередження про замороження кредитів та шахрайство є одними iз важливих кроки, які можуть вжити споживачі, щоб запобігти крадіжці особи. Викрадання особистих даних було другою за величиною категорією скарг споживачів, повідомлених FTC у 2017 році - 14 відсотків усіх скарг споживачів. Споживачі, які вважають, що стали жертвою крадіжок особи, можуть повідомити про це та отримати персональний план відновлення на спеціальному сайті «IdentityTheft. gov».

Виходячи 3 результатів дослідження, пропонуємо наступні варіанти поліпшення проведення політики захисту споживачів в Україні на законодавчому рівні:

1) Забезпечити жорстке виконання чинного законодавства для захисту споживачів та підтримки рівних умов для всіх суб'єктів ринку.

2) Прийняти законопроект «Про захист прав позичальників небанківських кредитів». Даний правовий акт передбачає низку обмежень саме небанківських фінансових установ. Головними умовами даного законопроекту повинні бути:

- максимальні ставки і максимальні внески за кредитами повинні не первищувати 180\%, щодо кредиту терміном до 90 днів, 100\% - від 90 днів до 1 року та 60\% -* більше 1 року;

- розмір внеску по кредиту не перевищувати 40\% мінімальної зарплати, по кредиту без довідки про доходи та не більше 40\% від середньомісячної заробітної плати позичальника за останні шість місяців, по кредиту 3 довідкою про доходи. Дана умова дозволить забезпечити стабільність як платникам, так і кредиторам, за рахунок невеликих, але постійних платежів;

- заборона встановлювати комісію за зарахування коштів та проведення інших платежів позичальника, передбачених договором кредиту, що забезпечить виведення із ринку шахрайських організацій та недобросовісних фінансових установ.

3) Визначити та законодавчо закріпити швидкість процесу закупівлі, що не призведе до негативного рішення. Забезпечить позичальників інтернеткредитів більшим часом на роздуми про отримання кредиту.

4) Ввести в дію цифрову та біометричну ідентифікацію особи. . Ідентифікація та авторизація клієнтів - одне 3 найважливіших завдань для фінансових організацій. Ідентифікація користувача за голосом, відбитками пальців i завдяки розпізнаванню обличчя змінює уявлення про надійність і безпеку при проведенні фінансових операцій.

5) Розробити та впровадити Моніторинг технологічних розробок та проектно-нейтральне законодавство, для того, щоб відповідні органи нагляду та регулювання могли постійно проводити моніторинг та оцінювання нових технологічних розробок та їх впливу на споживачів, що в свою чер- 
гу буде направлене на розробку технологічно нейтрального законодавства, яке $\epsilon$ достатньо універсальним для захисту споживачів незалежно від нових технологій, які можуть виникнути.

Висновки. Запропоновані зміни дозволять збалансовано підійти до проблеми захисту споживачів мікрокредитування, 3 одного боку не створюючи стимулів позичальнику уникати своїх зобов'язань, а з іншого не дозволяючи недобросовісному позичальнику збанкрутувати внаслідок отримання маленького кредиту.

\section{Список використаної літератури}

1. Fintech - статистика та факти. Statista. 2018. URL: https://www.statista.com/topics/2404/fintech/, 2018.

2. Зростання інтернет-кредитування в Україні. Об'єднання фінансових установ. 2019. URL: https://afi.org.ua/articles/kozhniy-shostiy-ukrayinec-do-kincya-rokuvizme-kredit-onlayn.

3. Позика онлайн: чи дійсно бувають кредити без процентів. URL: https://zik.ua/news/2019/08/31/pozyka_onlayn_chy_diysno_buvayut_kredyty_bez_pr otsentiv_1637815.

4. Офіційний сайт ФК «Moneyveo». URL: https://moneyveo.ua.

5. Офіційний сайт ФК «MyCredit». URL: https://mycredit.ua.

6. Офіційний сайт ФК «Milion». ТОВ «Безпечне агенство необхідних кредитів». URL: https://miloan.ua.

7. Офіційний сайт ФК «Dinero». ТОВ «Фінансова компанія «ДIHEPO»». URL: https://www.dinero.ua.

8. Про споживче кредитування: Закон України від 15 лис.2016 р. № 1734-VIII. URL: https://zakon.rada.gov.ua/laws/show/1734-19 (дата звернення: 24.09.2019).

9. Про затвердження Методичних рекомендацій щодо укладення електронних договорів про надання коштів у позику, в тому числі і на умовах фінансового кредиту, в інформаційно-телекомунікаційних системах: Розпорядження Нацкомфінпослуг. URL: https://www.nfp.gov.ua/files/ROZPORYADGHRNYA /2019/06-06/R-1033.pdf.

10. Про затвердження додаткових вимог до договорів про надання коштів у позику, в тому числі і на умовах фінансового кредиту»: Розпорядження Нацкомфінпослуг URL: https://www.nfp.gov.ua/files/ROZPORYADGHRNYA/ 2019/ 04- 07/R-1268.pdf 
11. Behavioural study on the digitalisation of the marketing and distance selling of retail financial services. European Union. URL: https://ec.europa.eu/ info/sites/info/files/live_work_travel_in_the_eu/consumers/digitalisation_of_financia 1_services_-_executive_summary_-_en_0.pdf.

12. Free credit freezes. trade commission. URL: https://www.consumer.ftc.gov/blog/2018/09/free-credit-freezes-are-here.

13. Бачо Р. Й. Державне регулювання ринків небанківських фінансових послуг України: ретроспективний аналіз. Теорія та практика державного управління. 2014. №4. С. 1-11.

14. Пам'ятка споживачу небанківських фінансових послуг. Національна комісія, що здійснює державне регулювання у сфері ринків фінансових послуг. URL: https://nfp.gov.ua/files/DepFinMon/\%D0\%91\%D0\%A0\%D0\%9E\%D0\% A8\%D0\%A 3\%D0\%A0\%D0\%90.pdf. 